Published in final edited form as:

Best Pract Res Clin Haematol. 2011 June ; 24(2): 147-163. doi:10.1016/j.beha.2011.02.006.

\title{
Transformation of Follicular Lymphoma
}

\author{
Izidore S. Lossos ${ }^{1}$ and Randy D. Gascoyne ${ }^{2}$ \\ ${ }^{1}$ Departments of Medicine \& Division of Hematology/Oncology, University of Miami, Sylvester \\ Comprehensive Cancer Center, Miami, Florida, USA
}

${ }^{2}$ Department of Pathology \& Laboratory Medicine and Experimental Therapeutics, British Columbia Cancer Agency and the BC Cancer Research Centre, Vancouver, BC, Canada

\begin{abstract}
Histological transformation of follicular lymphoma (FL) to a more aggressive non-Hodgkin's lymphomas is a pivotal event in the natural history of FL and is associated with poor outcome. While commonly observed in clinical practice and despite multiple studies designed to address its pathogenesis, the biology of this process represents an enigma. In this chapter we present a state of the art review summarizing the definition of histologic transformation, its incidence, pathogenesis, clinical manifestations, treatment and outcome. Furthermore, we specifically emphasize gaps in our knowledge that should be addressed in future studies.
\end{abstract}

\section{Keywords}

transformation; follicular lymphoma; DLBCL; $M Y C$; transplantation

\footnotetext{
(C) 2011 Elsevier Ltd. All rights reserved.

Address correspondence and reprint requests to: Dr. Izidore Lossos Department of Medicine Division of Hematology/Oncology Sylvester Comprehensive Cancer Center University of Miami 1475NW 12th Ave (D8-4) Miami, FL 33136, USA. Tel: (305) 243-4785, Fax: (305) 243-4787, Ilossos@med.miami.edu.

Publisher's Disclaimer: This is a PDF file of an unedited manuscript that has been accepted for publication. As a service to our customers we are providing this early version of the manuscript. The manuscript will undergo copyediting, typesetting, and review of the resulting proof before it is published in its final citable form. Please note that during the production process errors may be discovered which could affect the content, and all legal disclaimers that apply to the journal pertain.

Practice Points

- Heightened clinical suspicion is necessary to diagnose high-grade transformation of FL

- $\quad$ Biopsies should be performed in every patient with FL at the time of relapse, especially if the later is characterized by sudden rise in $\mathrm{LDH}$, rapid discordant localized nodal growth, new involvement of unusual extra-nodal sites, new onset of B symptoms or the development of hypercalcemia

- An attempt should be made to demonstrate a clonal relationship between the preceding FL and subsequent aggressive lymphoma

Research Agenda

- Investigation of the optimal therapeutic approach for patients at the time of transformation

- Examine the role of the microenvironment in the process of transformation and develop robust biomarkers that can be assessed in the routine laboratory setting

- Determine the existence and potential role of a FL stem cell or repopulating cell as a potential cell of origin contributing to histologic transformation
}

Conflict of interest statement

No conflicts of interest to declare. 


\section{Introduction}

Follicular lymphoma (FL) is an incurable and fatal malignancy with a median survival of 8-10 years. Although initially an indolent disease sensitive to a variety of chemotherapeutic agents, FL exhibits a continuous pattern of relapses with decreasing sensitivity to chemotherapy. A pivotal event in the natural history of FL is histological transformation to more aggressive malignancies, most commonly diffuse large B cell lymphomas (DLBCL) [1-15], although transformation to a histology with some resemblance to Burkitt lymphoma can be seen (now commonly referred to as unclassifiable B cell lymphoma with features intermediate between diffuse large B cell lymphoma and Burkitt lymphoma)[16]. In addition, lymphoblastic lymphoma and acute lymphoblastic leukemia (ALL) have also been rarely reported[17, 18]. In this process a more virulent subclonal population of cells emerge, typically associated with the loss of the follicular growth pattern, a rapidly progressive clinical course refractory to treatment, and short survival (commonly of less than 2 years) $[6$, $7,10,19]$. Although one of the earliest descriptions of FL transformation was reported more than 65 years ago by Gall and Mallory[20], this biological process and clinical event still remains incompletely understood[21] with many unanswered questions ranging from the reproducible definition of histologic transformation, its incidence and underlying biology, to the ability to predict its occurrence and the selection of the best therapeutic approach.

\section{Definition of FL transformation}

FL is a distinct clinicopathological entity composed of cells arranged in follicles that are morphologically and immunophenotypically similar to lymphocytes of the normal germinal center (GC) from which they are thought to originate. The current gold standard definition of higher-grade transformation to more aggressive lymphomas is based on a histological demonstration of an increase in the proportion of large cells infiltrating the lymph nodes diffusely and leading to effacement of the follicular architecture. Consequently, transformation is defined as pathologically demonstrated and clonally confirmed progression of FL grade 1, 2 and 3a to DLBCL or less commonly the intermediate gray-zone category of unclassifiable B cell lymphoma (hereafter referred to as BCLU), lymphoblastic lymphoma and ALL[22]. The simultaneous presence of FL and DLBCL in the same initial diagnostic biopsy represents composite histology, a finding that implies but does not confirm early transformation of FL and a likely clonal relationship between the two tumors. Consequently some investigators require at least a 6 month interval between the initial FL to diagnosis of DLBCL in order to unequivocally define it as a transformation[6, 10, 13]. Progression from FL grade 1 and 2 to FL grade 3a is not considered histologic transformation, but a common progression event during the course of disease[23]. Similarly, progression from a predominantly follicular growth pattern at diagnosis to an overtly diffuse architecture, not associated with transition of small centrocytes to large centroblasts, is also not considered frank transformation. In addition to biopsy proven evidence of progression to an aggressive lymphoid malignancy, an unequivocal definition of transformation requires demonstration of a clonal relationship between the original FL and subsequent neoplasm[24-29]. This can be established by molecular techniques demonstrating use of the same immunoglobulin gene comprised of variable $(\mathrm{VH})$, diversity $(\mathrm{D})$ and joining $(\mathrm{JH})$ segments that shares a backbone of common somatic mutations, thus allowing inference of a common progenitor cell. Molecular studies of Richter's transformation of chronic lymphocytic leukemia to DLBCL demonstrated that while some of the paired tumors indeed demonstrate identical or related $I G$ sequences, confirming a clonal relationship, others exhibited the presence of different molecular B cell clones, suggesting the presence of a molecularly unrelated second malignancy[30]. However, since in daily clinical practice $I G$ cloning and sequencing are not routinely performed, demonstration of light chain restriction by flow cytometry or immunohistochemistry may be sufficient to suggest transformation and rule out the 
appearance of an unrelated second malignancy. While transformed DLBCL frequently maintain the GC immunophenotype of the preceding FL and thus express CD10 and BCL6, antigenic drift may occur during the transformation process and thus loss or gain of antigenic markers may be observed and does not preclude a clonal relationship between the FL and subsequent transformed histology[31].

Clinical diagnosis of a transformation in patients for whom a biopsy was not performed was used in some studies[13, 15]. For example, Al-Tourah et al[15] established a clinical diagnosis of transformation based on the presence of at least one of the following: sudden rise in LDH, rapid discordant localized nodal growth, new involvement of unusual extranodal sites, new B symptoms and new hypercalcemia. However, clinical criteria may not correctly identify all the patients, since some of these symptoms may be associated with FL progression without histological evidence of transformation, while in other cases transformation may not be associated with any of these symptoms. Consequently, in all cases raising clinical suspicion of transformation at the time of disease progression and/or relapse, a biopsy should be obtained.

\section{Incidence of transformation}

The reported frequency of higher-grade FL transformation varies significantly, ranging from $10 \%$ to $60 \%$ of patients (Table 1). The wide range of reported frequency of the higher-grade histological transformation most probably relates to the methodological differences in the reported studies. Such differences include the policy regarding re-biopsy of relapse or disease progression, variable inclusion of autopsy data in the different series, inclusion of cases in which transformation was defined by clinical characteristics and variable duration of FL patients' follow-up and surveillance. Most previous clinical and pathological surveys assessing the frequency of FL transformation did not determine the clonality of the paired pre-and post-transformation lymphomas and thus did not distinguish between a true histological transformation (which represent evolution of the same clone) versus secondary de novo aggressive lymphomas, which are clonally unrelated to the antecedent FL and thus do not represent true transformation. Moreover, the reported frequency of FL transformation also depends on the size of the cohort used for analysis. No prospective studies with predefined uniform criteria for re-biopsy have been performed and all the reported studies are based on retrospective reviews. Therefore, in the absence of prospective long-term studies with an aggressive policy of re-biopsy for all suspected clinical transformations and/or new lesions, the true frequency of histological transformation of FL cannot be reliably estimated. Acker $\mathrm{et} \mathrm{al} \mathrm{reported} \mathrm{transformation} \mathrm{risk} \mathrm{of} 20 \%$ at 5 years and $60 \%$ at 8 years of observation[7]. Ersboll et al [12] and Montoto et al [14], who defined transformation solely by histological criteria, reported $30 \%$ and $17 \%$ of transformation at 5 years and $56 \%$ and $28 \%$ probability of transformation at 10 years, respectively. Bastion et al[13] and Al-Tourah et al[15], who defined transformation by either histological or clinical criteria, reported $22 \%$ and $15 \%$ probability of transformation at 5 years and $31 \%$ and $30 \%$ probability of transformation at 10 years, respectively. Overall, these studies suggest a cumulative rate of transformation of 3\% per year. While Bastion et al[13] and Montoto et al[14] suggested the presence of a plateau in the risk of transformation after 6 and 12 years of follow up, respectively, with no further increase in the rate of transformation during longer follow up, there was no evidence of a plateau in the risk of transformation in the studies by Horning $e t$ al[9] and Al-Tourah et al[15], indicating a continuous increase in the actuarial risk of FL transformation over time. This increase in the probability of transformation over time and its occurrence in both treated and un-treated FL patients suggest that the change to a more aggressive histology associated with a more aggressive clinical behavior may represent an inherent potential of FL. 


\section{Pathology of FL}

FL represents a tumor of B cell type that histologically recapitulates follicle formation reminiscent of benign, secondary lymphoid follicles. The cytology of the malignant follicles in FL shows a variable number of small cells (centrocytes) and large, transformed cells referred to as centroblasts. The absolute numbers of these cells within neoplastic follicles is used to establish grade[16]. True follicular grade $3 b$ FL is a very uncommon lymphoma and considered by many to be biologically unrelated to the more common FL histologies encompassing grade 1-3a FL[16]. A number of immunophenotypic and genetic features suggest that grade $3 \mathrm{~b}$ FL maybe more akin to de novo DLBCL, however, most clinical studies have not shown a survival difference between grade $3 \mathrm{a} v s \mathrm{~b}$ FL if cases with a diffuse component are excluded[32, 33]. True follicular architecture may be very subtle in some cases and is most easily appreciated when immunohistochemical stains for follicular dendritic cells (FDC) are used. Antibodies to CD21, CD23, CD35 or undefined reagents such as CNA.42 are very useful for this purpose and are largely under-utilized in routine pathology practice. As noted previously, true diffuse variants of FL exist but are very uncommon[16]. These cases should lack follicle formation, show a mixture of centrocytes and centroblasts but lack foci of true transformation (sheets of centroblasts), and typically show phenotypic $\left(\mathrm{CD} 10^{+}, \mathrm{BCL}^{+}\right)$and genetic features (presence of the $\mathrm{t}(14 ; 18)$ ) otherwise characteristic of FL[16].

Transformation of FL must be distinguished from composite histologies seen not uncommonly at the time of diagnosis. Lymph node biopsies showing variable architecture and harboring two distinct histologies is most frequently seen in the context of FL. If one part of the lymph node shows grade 1-3a FL, while the other shows DLBCL, then both diagnoses must be recorded. Although infrequently established, the implication is that the DLBCL component arose as a result of an early transformation event in the FL B cells. Such cases are not typically included in series of FL transformation.

The immunophenotype of FL is similar to germinal center B cells. The neoplastic cells of FL typically express CD19, CD20, CD22, and CD79a and show surface Ig expression (sIG of $\operatorname{IgM}+/-\operatorname{IgD}, \operatorname{IgG}$ or rarely $\operatorname{IgA}$ ). Most cases are positive for BCL2, BCL6 and CD10. Typically CD5 and CD43 are negative. CD10 and BCL6 are often down-regulated and show less intense staining in the inter-follicular regions. Both HGAL and LMO2 have recently been shown to be very useful markers in the diagnosis of FL, particularly in cases with variant immunoarchitectural patterns[34]. The proliferative rate of FL is typically low, but can be quite variable and may be associated with outcome[35, 36]. A subset of grade $3 b$ FL cases may show less frequent expression of CD10, may express MUM1 and may lack $\mathrm{t}(14 ; 18)$ and reveal $B C L 6$ translocations[37-39].

Cytogeneti c studies in FL characteristically reveal the presence of the $t(14 ; 18)$ in approximately $85 \%$ of cases[40, 41]. Rarely is this the only change, as some degree of karyotypic evolution is almost always found. Common secondary changes include gains of chromosome 6p, 7, 8, 12q, 18, X and the derivative 18q[40-44]. Losses of cytogenetic material include 1p, 6q, 10q and 17p [40, 41, 44, 45]. Balanced translocations other than the characteristic $\mathrm{t}(14 ; 18)$ are uncommon, but include $B C L 6$ in some cases[46-53]. Roughly $10-15 \%$ of FL cases lack a $\mathrm{t}(14 ; 18)$ and this may be associated with a lack of BCL2 protein expression and more frequent $B C L 6$ translocations[48, 49, 51-55].

\section{Pathology of FL transformation}

Transformation of FL represents a spectrum of histologies, many of which can be difficult to classify using a World Health Organization (WHO) schema largely established for de novo NHLs (see Table 2). The most common histology identified in follow-up biopsies of patients 
with FL is DLBCL (see Figure 1). These cases typically reveal classic centroblastic morphology, but may show vague remnants of the underlying FL. The second most common histology encountered is largely encapsulated with the new WHO gray zone category of unclassifiable B cell lymphoma with features intermediate between DLBCL and Burkitt lymphoma (BL)[22]. This category contains cases previously diagnosed as Burkitt-like lymphoma; terminology that is no longer recommended[56,57]. These cases show a diffuse architecture with a mixture of medium-to large transformed cells and may reveal a starrysky pattern and moderate numbers of mitotic figures[22, 58, 59]. A resemblance to BL is often found, particularly at low magnification. However, variation in nuclear size and shape typically precludes a straight-forward diagnosis of BL. These cases typically show uniform BCL2 protein expression and the BCLU category is enriched for dual-translocation/doublehit lymphomas harboring both $B C L 2$ and $M Y C$ translocations[22, 58]. Dim CD20 expression has also been recently described as a feature of double-hit lymphomas[60]. Half of the double-hit lymphomas in clinical practice can arise de novo lacking a history of antecedent FL and present as aggressive neoplasms that are presumed to represent transformation of clinically silent FL[61-65]. Transformed FL should never be diagnosed as BL (exceptions would include a clonally unrelated BL as a second lymphoma), as the presence of the characteristic FL translocation, the $\mathrm{t}(14 ; 18)$, and strong cytoplasmic expression of BCL2 would by definition preclude a diagnosis of classic BL. Moreover, cytogenetic analysis of transformed FL would typically reveal cytogenetic complexity, a feature not found in de novo BL[66, 67].

Rarely, transformation of FL results in a histology and immunophenotype that overlaps with lymphoblastic lymphoma and/or ALL[17, 18, 63]. Adult presentations of ALL with cells expressing both surface IG and nuclear terminal deoxynucleotidyl transferase (Tdt) have been described, with and without a history of FL[63, 68]. Cytogenetic studies often show both BCL2 and MYC translocations or so-called double-hit disease. Similarly, lymph node or extranodal biopsies of clinically transformed sites in FL may show sheets of medium sized blast cells with immature chromatin and frequent mitoses[22, 23]. Similarly, these cases often reveal double-hit cytogenetics with both $B C L 2$ and MYC translocations, but the most recent $2008 \mathrm{WHO}$ classification does not recommend classifying $\mathrm{Tdt}^{+}$cases as BCLU[22]. Finally, rare blastoid histologies can be encountered at the time of FL transformation and if $\mathrm{Tdt}^{-}$, are considered transformed disease[69].

In most cases, the phenotype of transformed FL mimics the underlying FL[24, 70, 71]. The majority of cases retain expression of CD10, BCL6 and BCL2, although rare cases may lose expression of one or more antigens. At the molecular level, FL is of GCB type and this expression pattern is typically maintained in the transformed biopsy[71]. Concomitant with the transformation is loss of the follicular architecture and an increase in the mitotic rate in large part due to the increased centroblasts. More common changes in the immunophenotype relate to changes in the non-neoplastic cells. For example, the numbers of T cells tends to diminish and the FDCs completely disappear or represent only vague, poorly defined meshworks.

The cytogenetic findings in transformed FL samples have already been eluded too, as the acquisition of a MYC translocation on a background of $\mathrm{t}(14 ; 18)$ can be found in this setting and defines a case as double-hit or dual translocation associated with very aggressive clinical behavior[63, 64]. Rare cases may show both a BCL6 and MYC translocation in the transformed nuclei, however the clinical significance of this finding is less clear than concurrent $B C L 2$ and $M Y C$. Typically the karyotype is complex and is frequently associated with many of the secondary changes described in the section below describing genetic factors associated with FL transformation[64, 72, 73]. 


\section{Biology of FL}

The etiology of FL is largely unknown. The pathogenesis is best explained by a unifying hypothesis that takes into account genetic alterations harbored by the neoplastic B cells and an immunological model that suggests prominent crosstalk between the tumor cells and nonneoplastic immune cells in the tumor microenvironment[21, 74, 75]. The latter includes a number of $\mathrm{T}$ cell subsets, macrophages, follicular dendritic cells and stromal elements[70, $74,76]$. Briefly, the $t(14 ; 18)$ characteristic of most cases of FL leads to constitutive BCL2 protein expression and is a critical early event in the development of FL. These cells then slowly proliferate, but importantly, do not die by apoptosis. Some of the genetic alterations that follow may be passenger mutations. These can include even gross chromosomal changes that result from localization in the germinal center milieu where double-stranded DNA breaks are physiological[77]. Others are driver mutations and alterations that provide the malignant cells with a growth advantage including gains, losses of chromosomal material and even balanced translocations involving dominant oncogenes such as MYC. Several recent studies have shown divergent pathways of disease progression and transformation in FL. These data suggest that FL may evolve along a number of pathways and that at least in some cases transformation may arise from an earlier subclone or even a common progenitor cell[ $45,78-81]$. Novel bioinformatics approaches have identified that a network of gene transcriptional modules enriched for pluripotency-related genes underlies transformation of FL[82, 83].

\section{Pathological and biological factors associated with FL transformation}

A number of factors have been implicated in the biology of FL transformation[21, 73, 75]. Some of these factors have been shown to generally affect prognosis in FL while others have specifically been studied in the context of histological transformation[21, 73, 75]. The following discussion will examine those factors implicated in transformation of FL.

The approach to studying transformation in FL has followed two lines of investigation. Most analyses have utilized paired samples from individual patients with FL and their subsequent transformed DLBCL specimens. The alternative approach has been to study cohorts of FL, ideally with uniform therapy, to determine biomarkers harbored by the FL cells or features of the microenvironment that predict for subsequent transformation. Both approaches have merit.

Although a large number of prognostic markers have been implicated as contributing to survival in FL, only a handful have specifically examined the role of biological factors impacting risk of transformation (see Table 3 and Figure 2)[21, 73, 75]. Most follicular lymphoma B cells depend on the underlying FDCs for their growth and survival. Loss of the FDC meshworks and subsequent dissolution of follicles is considered a harbinger of early transformation of FL[84]. Similarly, areas with diffuse architecture appear to be associated with an increased risk of transformation[33]. In some cases these changes are associated with epigenetically-regulated loss of CD9 expression by the FL cells upon transformation, contributing to an FDC-independent growth of these tumors[85]. A number of genetic aberrations found in FL B cells have been associated with histologic transformation. An analysis of paired samples was first used to implicate mutations in p53 (chromosome 17p) as an important genetic event underlying histologic transformation of FL[86, 87]. In general, mutations in $p 53$ were found in the DLBCL that were not present in the pre-existing FL. A similar approach was used to implicate alterations in p16 (chromosome 9p), including deletions, mutations and increased promoter methylation, leading to diminished p16 expression in the transformed biopsies[88]. Gene expression studies of paired samples demonstrate that FL transformation is associated with changes in expression of $M Y C$ and its 
target genes[24, 71, 89]. These changes could be attributed to $M Y C$ mutations and translocations in a small fraction of the cases, but no structural aberrations were identified in the majority of the cases[24]. The changes in the expression of $M Y C$ and its targets might reflect a more general change in the expression of a primitive stem cell gene signature upon transformation[24, 83]. The presence of $M Y C$ translocations in FL biopsies at diagnosis is uncommon, with some studies suggesting an association with an increased risk of transformation[61]. Increased expression of MDM2, a gene located within the 12q amplicon in FL has been associated with transformation risk in FL[90]. Similarly, gains of 12q13-14 as assessed by cytogenetics increase the risk of FL transformation as have gains of chromosome 7[91-93]. Somatic mutations in either BCL2 or BCL6 genes have also been associated with histologic transformation, while BCL6 translocation in diagnostic FL specimen was suggested to predispose to subsequent transformation[27, 94, 95]. More recently, genetic alterations involving chromosome 1 p36.3 has been shown to be a very frequent acquired genetic alteration in FL and has been associated with an increased risk of transformation[44, 96]. This region is targeted by deletions, acquired uniparental dizomy (UPD) or copy-neutral loss of heterozygosity and mutations. Cheung and colleagues have shown that TNFRSF14 is the likely candidate gene in the locus and maybe a critical new tumor suppressor gene[97]. Mutations in FAS, mapping to chromosome 10q have also been suggested to contribute to an increased risk of histologic transformation[29, 98]. Lastly, acquired UPD involving chromosome $16 \mathrm{p}$ has also been recently shown to predispose to transformation in FL[99]. The gene(s) involved have not yet been identified.

More recently, attention has been turned to examining the contribution of non-neoplastic immune cells in the tumor microenvironment and their contribution to FL biology[21, $74-76,100]$. The list of cells includes a number of $\mathrm{T}$ cell subsets $\left(\mathrm{CD}^{+}, \mathrm{CD}^{+}\right.$, regulatory $\mathrm{T}$ cells, PD-1 ${ }^{+}$T cells), macrophages and endothelial cells represented by microvessel density. The impact of these prognostic biomarkers on both survival and risk of histologic transformation has been somewhat controversial, in-part due to the heterogeneity of treatments and patient characteristics of the reported studies[101]. Both the immunoarchitectural pattern and content of $\mathrm{CD}^{+}{ }^{+} \mathrm{T}$ cells and regulatory $\mathrm{T}$ cells have been shown to predict risk of transformation[70]. Initial studies in FL with patients exposed to markedly variable treatments suggested that decreased regulatory $\mathrm{T}$ cells, as measured by nuclear FOXP3 staining, were associated with an increased risk of transformation[102]. Subsequently, a study of uniformly treated patients showed that a follicular and/or perifollicular pattern of Treg cells increased the likelihood of transformation[103]. A low number of PD-1 ${ }^{+} \mathrm{T}$ cells have also been associated with increased frequency of transformation[104]. All of these studies pre-date the use of rituximab alone or in combination with multi-agent chemotherapy and thus the role of non-neoplastic cells will need to be re-visited in the current era of therapy[105, 106]. Lastly, increased microvessel density in FL biopsies has been shown to increase the risk of transformation[107]. In aggregate these data suggest that in addition to genetic alterations harbored by the malignant cells in FL, crosstalk between the tumor cells and non-neoplastic immune cells in the tumor microenvironment also affects the risk of transformation in FL.

\section{Clinical characteristics of FL transformation}

There are no specific clinical characteristics at the time of initial FL diagnosis that can reproducibly predict future higher-grade transformation. In general, clinical characteristics associated with poor prognosis of patients with FL are also linked to the risk of transformation. Several studies reported higher risk of transformation in patients with advanced disease stage, presence of B symptoms and bulky disease, high $\beta 2$ microglobulin and low albumin levels as well as higher scores of follicular lymphoma international prognostic index (FLIPI) and international prognostic index (IPI)[13-15, 108]. Montoto et 
al[14] reported a higher risk of transformation in patients undergoing expectant management at diagnosis, but Horning et al[9] and Al-Tourah et al [15] demonstrated a similar risk of transformation in patients whose therapy was deferred versus those who were treated at diagnosis. Overall, the currently available data suggest that early initiation of FL treatment does not decrease the risk of transformation.

The clinical presentation at the time of higher-grade transformation is variable. Consequently, higher-grade transformation should be suspected in every FL patient at the time of disease progression or relapse. It is often heralded by rapid and commonly discordant growth of localized lymph nodes that may be associated with pain, appearance of unusual extranodal involvement (e.g. central nervous system, liver and bone), sudden and excessive rise in levels of LDH or development of new B symptoms that can be observed in 30 to $56 \%$ of patients. New onset hypercalcemia can also be detected[15], but this is a rare manifestation of FL transformation. Most patients at the time of transformation present with an advanced extent of their disease (stage III /IV or bulky stage I/II disease with new B symptoms); however, transformation may also be diagnosed in patients with limited disease[109]. Moreover, FL transformation can also be diagnosed in the absence of all these clinical features at the time of a clinically asymptomatic FL relapse manifested by reappearance of enlarged lymph nodes. Therefore, a high level of clinical suspicion and performance of an excisional biopsy are necessary for unequivocal diagnosis of FL transformation. Performing a PET-CT at the time of the suspected transformation may help to guide the selection of the lymph node for biopsy, since lymph nodes with transformed disease more commonly exhibit higher standardized uptake values (SUVs) on the positron emission tomography (PET) scanning[110].

The median time from diagnosis to transformation in the reported series ranges from 40 to 66 months, with the earliest transformation reported at 2 months and the latest at 25 years[13-15]. Transformation may occur at the time of the first or any of the subsequent progressions or recurrences in patients undergoing either expectant follow-up or during and after therapy. While most studies do not report association with any specific therapeutic approach and risk of transformation, Al-Tourah et al[15]reported a higher risk of transformation in patients treated with a combination of an alkylator and a purine analog compared to patients that received chemotherapy consisting of bleomycin, cisplatin, etoposide, doxorubicin, cyclophosphamide vincristine and prednisone followed by moderate dose of radiation to previously involved nodal sites. Higher risk of transformation was associated in some studies with an inability to achieve complete response (CR) after initial FL therapy and the need of two or more treatments to control initially symptomatic FL[13, $15]$.

\section{Prognostic factors and outcome of patients with higher-grade transformation of FL}

While the clinical course of FL patients may span a decade or more, transformation occurrence heralds a change from an indolent to an aggressive disease course associated with major morbidity and mortality. Most studies have reported a poor prognosis after transformation with a median duration of survival ranging from 2.5 months to 2 years (Table 4). In the study by Acker et al[7], the median survival after transformation was 8.5 months, but patients achieving CR after transformation had a more favorable outcome with actuarial survival of $75 \%$ at 5 years. Hubbard et al[6] reported median survival after transformation of 11 month (CI 95\% 4-34 months) with marked difference between patients that achieved CR (median survival 40.5 months; range 12-88 month) and those who did not (median survival 4 months; range 1-26 month). Table 4 summarizes reported outcomes of patients post FL transformation. Only slight improvement in the outcome is observed in the recent studies. 
However, the more recent studies have demonstrated shorter overall survival of patients with transformation in comparison to non-transformed FL patients, clearly showing the significant adverse effect of transformation on survival. Indeed, most of the deaths in these patients are due to lymphoma. Most of the patients in the reported studies received therapies not incorporating rituximab. Whether rituximab addition will change prognosis of transformed FL patients needs to be addressed in the future studies.

The clinical and laboratory findings associated with better OS at the time of FL transformation include limited disease extent, good performance status, normal levels of $\mathrm{LDH}$, absence of B symptoms, transformation after expectant management, fewer number of previous relapses, history of $\mathrm{CR}$ to previous therapy and achievement of CR following salvage therapy given at the time of transformation[13-15, 109]. Despite the overall poor outcome of patients with FL transformation, Yuen et al identified a subset of patients having a relatively good outcome following transformation[109]. Significant and independent predictors of survival following FL transformation included limited extent of disease, attainment of CR to treatment given at the time of the transformation and no prior therapy. Moreover, among patients who attained a CR following transformation, those with limited disease and those with no prior chemotherapy had better prognosis. At the time of publication, this study differed from previously reported studies in several respects: 1) the median survival time after transformation in this study (22 months) was longer than reported by others; 2) the extent of disease at transformation in these patients was less than that reported in other series, with 50\% of cases presenting with limited disease; 3) lack of prior therapy in a significant proportion of cases included in this study might allow administration of greater doses of chemotherapy at the time of transformation and prevented development of drug resistance, thus lessening the chance of selection for drug resistant clones leading to transformation. However, more recent studies confirmed some of the findings reported by Yuen et al. Bastion et al [13]also demonstrated better outcome in patients with limited disease and those achieving CR in response to salvage therapy at the time of transformation. The impact of limited disease on patients' outcome was also demonstrated by Al-Tourah $e t$ $a l[15]$. Overall these finding may help to better tailor therapy for patients with transformed FL.

\section{Treatment of patients with FL transformation}

There are no prospective studies specifically evaluating treatment approaches in patients with transformed FL. Efficacy of different therapeutic regimens in these patients is reported mostly in small, retrospective cohorts of patients with variable follow-up. Consequently, these data are quite limited, making it difficult to derive a therapeutic approach based on solid clinical data. Furthermore, most of the published studies were conducted in the prerituximab era, precluding any conclusion on the potential role of rituximab in these patients.

Most patients following transformation are treated with standard doxorubicin-containing combination chemotherapy regimens, reported to lead to CR in 40\%[14, 109]and overall response in $60 \%[13,14]$ of patients. Radiation, either alone or in combination with chemotherapy, is used in patients with limited disease and may lead to a higher CR rate (70\%) [109]. However, since the observed response rates are lower and duration of response is shorter in post transformation patients compared to patients with de-novo DLBCL, with some patients unable to receive doxorubicin-containing combination chemotherapy regimen since it was already used during the indolent phase of FL, alternative therapeutic approaches are needed.

Radioimmunotherapy (RIT) using radioactive nucleotide labeled antibodies yttrium $\mathrm{Y}^{90}$ ibritumomab (Zevalin) and iodine $\mathrm{I}^{131}$ tositumomab (Bexxar), has been shown to exhibit 
anti-lymphoma activity in a small number of patients with transformed FL [111-114](Table 5). These patients received RIT either as the initial therapy for transformed FL or after they failed other therapeutic approaches. The overall response rate of transformed FL patients treated with RIT in these studies was 51\%, with 50\% of the responders achieving CR. Notably, many patients achieving CR demonstrated prolonged responses, frequently lasting longer than 12 months. These limited data demonstrates that RIT, well tolerated by most patients, shows clear activity in a fraction of patients with transformed FL and should be considered as a suitable therapeutic option. However, similar to patients receiving RIT for indolent FL, this approach is less effective in patients with bulky tumor burdens and patients who have received prior radiotherapy.

Because the responses achieved with conventional chemotherapy in patients with transformed FL are frequently of short duration and historically patients with transformed FL exhibit inferior outcomes with conventional-dose therapy, high-dose therapy and autologous stem cell transplantation (ASCT) were evaluated by several groups[115-124] (Table 6). These studies are mostly small, and heterogeneous in terms of eligibility criteria, definition of transformation and the timing of ASCT in the course of FL. While ASCT was performed in patients with chemoresistant or with residual disease at the time of transplantation in some studies[120], other studies proceeded with this treatment only in patients with minimal residual disease[117, 118, 121]. Overall, the available data supports the efficacy of this approach in patients with transformed FL. CR post ASCT is achieved in $40-100 \%$ of patients, with 5-year overall survival of 33-81\%. Whether ASCT for transformed FL leads to a PFS/EFS plateau is unclear, with some studies suggesting this finding $[117,119,120]$, while others do not $[118,121,123]$.

The major cause for treatment failure is relapse. While most relapses are due to DLBCL, FL recurrences may also be observed. Therefore, a biopsy should be performed at the time of post ASCT relapse to establish the subtype of the relapsed lymphoma. High LDH levels and presence of residual disease or chemoresistance at the time of transplantation[120, 122] and advanced age $[119,122]$ were associated with shorter post ASCT OS and PFS. Comparison of the transplantation outcomes between patients with transformed and non-transformed FL or de novo DLBCL demonstrated no significant differences in OS and PFS in some studies $[118,120]$, while others suggested inferior outcome for patients with transformed FL [122].

Given the high relapse rate seen with ASCT and the potential benefit of a graft-versuslymphoma effect, several investigators explored the role of allogeneic transplantation in patients with transformed FL. In a large study of 40 patients with transformed FL, allogeneic transplantation resulted in 2- and 5-year OS of $45 \%$ and 33\%, respectively, and corresponding EFS of 38 and 29\%[124]. These results were significantly inferior to the results of ASCT obtained in the same institution, most probably due to the higher treatment related mortality (TRM) associated with the allogeneic transplantation (35\% versus $10 \%$ at 5 years). Furthermore, the risk of disease relapse at 5 years was non-significantly lower in the recipients of the allogeneic transplantation. Overall, this study demonstrated that due to a similar risk of relapse and higher TRM, the outcome of the ASCT was superior to that of the allografted patients with transformed FL.

Revzani et al [125] evaluated the role of non-myeloablative allogeneic transplant in 16 patients with transformed FL. The outcome of patients with transformed FL was significantly worse than the outcome of patients with non-transformed FL, with 3-year PFS and OS of only $21 \%$ and $18 \%$, respectively. The aggressive clinical course of the transformed FL may not allow sufficient time for the development of the graft-versuslymphoma effect, leading to poor patient outcomes. While further studies evaluating the role 
of allogeneic transplantation in patients with transformed FL are needed, this is currently not considered a standard therapy for patients with transformed FL.

Based on the presently available published data, limited in scope and mostly derived from small retrospective studies, it is difficult to propose a standard and optimized therapeutic strategy for patients with transformed FL. However, some suggestions can be made based on the literature and our institutional experience, which need to be verified in prospective clinical trials. Overall, patients with transformed FL should be encouraged to participate in such prospective studies. If such studies are not available, the following approach can be considered (Figure 3):

A. Anthracycline-naïve patients with transformed FL should be treated with rituximab-CHOP. Patients with limited disease at the time of transformation should receive consolidation with involved field radiation.

B. Patients not achieving $\mathrm{CR}$ following rituximab-CHOP should receive salvage treatment and, if chemosensitive, proceed to ASCT. Alternatively, RIT can be considered for these patients.

C. Patients achieving CR following rituximab-CHOP can be either observed, especially if they did not receive prior therapy for indolent FL, or may be consolidated with ASCT or RIT. Currently, in the rituximab era, there are not enough data to suggest that consolidation with ASCT or RIT is superior to observation.

D. Patients treated with anthracycline-containing regimens prior to the transformation should receive standard salvage regimen followed by ASCT. Consideration can be given to consolidate these patients with RIT after salvage therapy.

\section{Acknowledgments}

National Institutes of Health (NIH) grants NIH CA109335 and NIH CA122105, and the Dwoskin Family Foundation. No role of study sponsors in this study.

\section{References}

1. Hicks EB, Rappaport H, Winter WJ. Follicular lymphoma; a re-evaluation of its position in the scheme of malignant lymphoma, based on a survey of 253 cases. Cancer. 1956; 9:792-821. [PubMed: 13356265]

2. Qazi R, Aisenberg AC, Long JC. The natural history of nodular lymphoma. Cancer. 1976; 37:19231927. [PubMed: 1260694]

3. Cullen MH, Lister TA, Brearley RI, et al. Histological transformation of non-Hodgkin's lymphoma: a prospective study. Cancer. 1979; 44:645-651. [PubMed: 383259]

4. Risdall R, Hoppe RT, Warnke R. Non-Hodgkin's lymphoma: a study of the evolution of the disease based upon 92 autopsied cases. Cancer. 1979; 44:529-542. [PubMed: 383257]

5. Ostrow SS, Diggs CH, Sutherland JC, et al. Nodular poorly differentiated lymphocytic lymphoma: changes in histology and survival. Cancer Treat Rep. 1981; 65:929-933. [PubMed: 7028254]

6. Hubbard SM, Chabner BA, DeVita VT Jr, et al. Histologic progression in non-Hodgkin's lymphoma. Blood. 1982; 59:258-264. [PubMed: 7034812]

7. Acker B, Hoppe RT, Colby TV, et al. Histologic conversion in the non-Hodgkin's lymphomas. J Clin Oncol. 1983; 1:11-16. [PubMed: 6366124]

8. Garvin AJ, Simon RM, Osborne CK, et al. An autopsy study of histologic progression in nonHodgkin's lymphomas. 192 cases from the National Cancer Institute. Cancer. 1983; 52:393-398. [PubMed: 6344979]

9. Horning SJ, Rosenberg SA. The natural history of initially untreated low-grade non-Hodgkin's lymphomas. N Engl J Med. 1984; 311:1471-1475. [PubMed: 6548796] 
10. Oviatt DL, Cousar JB, Collins RD, et al. Malignant lymphomas of follicular center cell origin in humans. V. Incidence, clinical features, and prognostic implications of transformation of small cleaved cell nodular lymphoma. Cancer. 1984; 53:1109-1114. [PubMed: 6692302]

11. Gallagher CJ, Gregory WM, Jones AE, et al. Follicular lymphoma: prognostic factors for response and survival. J Clin Oncol. 1986; 4:1470-1480. [PubMed: 3531422]

12. Ersboll J, Schultz HB, Pedersen-Bjergaard J, Nissen NI. Follicular low-grade non-Hodgkin's lymphoma: long-term outcome with or without tumor progression. Eur J Haematol. 1989; 42:155163. [PubMed: 2917634]

13. Bastion Y, Sebban C, Berger F, et al. Incidence, predictive factors, and outcome of lymphoma transformation in follicular lymphoma patients. J Clin Oncol. 1997; 15:1587-1594. [PubMed: 9193357]

14. Montoto S, Davies AJ, Matthews J, et al. Risk and clinical implications of transformation of follicular lymphoma to diffuse large B-cell lymphoma. J Clin Oncol. 2007; 25:2426-2433. [PubMed: 17485708]

15. Al-Tourah AJ, Gill KK, Chhanabhai M, et al. Population-based analysis of incidence and outcome of transformed non-Hodgkin's lymphoma. J Clin Oncol. 2008; 26:5165-5169. [PubMed: 18838711]

16. Swerdlow, SH.; Campo, E.; Harris, NL. WHO Classification of Tumours of Haematopoietic and Lymphoid Tissues. Switzerland World Health Organization; Geneva: 2008. al. e

17. De Jong D, Voetdijk BM, Beverstock GC, et al. Activation of the c-myc oncogene in a precursorB-cell blast crisis of follicular lymphoma, presenting as composite lymphoma. N Engl J Med. 1988; 318:1373-1378. [PubMed: 3285208]

18. Gauwerky CE, Haluska FG, Tsujimoto Y, et al. Evolution of B-cell malignancy: pre-B-cell leukemia resulting from MYC activation in a B-cell neoplasm with a rearranged BCL2 gene. Proc Natl Acad Sci U S A. 1988; 85:8548-8552. [PubMed: 3186743]

19. Armitage JO, Dick FR, Corder MP. Diffuse histiocytic lymphoma after histologic conversion: a poor prognostic variant. Cancer Treat Rep. 1981; 65:413-418. [PubMed: 7016324]

20. Gall EA, Mallory TB. Malignant Lymphoma: A Clinico-Pathologic Survey of 618 Cases. Am J Pathol. 1942; 18:381-429. [PubMed: 19970634]

21. Lossos IS. Higher-grade transformation of follicular lymphoma -- a continuous enigma. Leukemia. 2005; 19:1331-1333. [PubMed: 15902286]

22. Kluin, PM.; Harris, NL.; Stein, H., et al. B-cell lymphoma, unclassifiable, with features intermediate between large B-cell lymphoma and Burkitt lymphoma.. In: Swerdlow, SH.; Campo, E.; Harris, NL., et al., editors. WHO classification of tumours of haematopoietic and lymphoid tissues. Edition 4th. IARC; Lyon: 2008. p. 265-266.

23. Muller-Hermelink HK, Zettl A, Pfeifer W, Ott G. Pathology of lymphoma progression. Histopathology. 2001; 38:285-306. [PubMed: 11318894]

24. Lossos IS, Alizadeh AA, Diehn M, et al. Transformation of follicular lymphoma to diffuse largecell lymphoma: alternative patterns with increased or decreased expression of c-myc and its regulated genes. Proc Natl Acad Sci U S A. 2002; 99:8886-8891. [PubMed: 12077300]

25. Lossos IS, Levy R. Higher grade transformation of follicular lymphoma: phenotypic tumor progression associated with diverse genetic lesions. Semin Cancer Biol. 2003; 13:191-202. [PubMed: 12959350]

26. Lossos IS, Thorstenson YR, Wayne TL, et al. Mutation of the ATM gene is not involved in the pathogenesis of either follicle center lymphoma or its transformation to higher-grade lymphoma. Leuk Lymphoma. 2002; 43:1079-1085. [PubMed: 12148890]

27. Lossos IS, Warnke R, Levy R. BCL-6 mRNA expression in higher grade transformation of follicle center lymphoma: correlation with somatic mutations in the 5' regulatory region of the BCL-6 gene. Leukemia. 2002; 16:1857-1862. [PubMed: 12200704]

28. Martinez-Climent JA, Alizadeh AA, Segraves R, et al. Transformation of follicular lymphoma to diffuse large cell lymphoma is associated with a heterogeneous set of DNA copy number and gene expression alterations. Blood. 2003; 101:3109-3117. [PubMed: 12406872] 
29. Do B, Lossos IS, Thorstenson Y, et al. Analysis of FAS (CD95) gene mutations in higher-grade transformation of follicle center lymphoma. Leuk Lymphoma. 2003; 44:1317-1323. [PubMed: 12952224]

30. Matolcsy A, Inghirami G, Knowles DM. Molecular genetic demonstration of the diverse evolution of Richter's syndrome (chronic lymphocytic leukemia and subsequent large cell lymphoma). Blood. 1994; 83:1363-1372. [PubMed: 8118038]

31. Maeshima AM, Omatsu M, Nomoto J, et al. Diffuse large B-cell lymphoma after transformation from low-grade follicular lymphoma: morphological, immunohistochemical, and FISH analyses. Cancer Sci. 2008; 99:1760-1768. [PubMed: 18549405]

32. Chau I, Jones R, Cunningham D, et al. Outcome of follicular lymphoma grade 3: is anthracycline necessary as front-line therapy? Br J Cancer. 2003; 89:36-42. [PubMed: 12838297]

33. Hans CP, Weisenburger DD, Vose JM, et al. A significant diffuse component predicts for inferior survival in grade 3 follicular lymphoma, but cytologic subtypes do not predict survival. Blood. 2003; 101:2363-2367. [PubMed: 12424193]

34. Younes SF, Beck AH, Lossos IS, et al. Immunoarchitectural Patterns in Follicular Lymphoma: Efficacy of HGAL and LMO2 in the Detection of the Interfollicular and Diffuse Components. Am J Surg Pathol. 2010

35. Wang SA, Wang L, Hochberg EP, et al. Low Histologic Grade Follicular Lymphoma With High Proliferation Index: Morphologic and Clinical Features. Am J Surg Pathol. 2005; 29:1490-1496. [PubMed: 16224216]

36. Martin AR, Weisenburger DD, Chan WC, et al. Prognostic value of cellular proliferation and histologic grade in follicular lymphoma. Blood. 1995; 85:3671-3678. [PubMed: 7780151]

37. Guo Y, Karube K, Kawano R, et al. Bcl2-negative follicular lymphomas frequently have Bcl6 translocation and/or Bcl6 or p53 expression. Pathology international. 2007; 57:148-152. [PubMed: 17295647]

38. Karube K, Guo Y, Suzumiya J, et al. CD10-MUM1+ follicular lymphoma lacks BCL2 gene translocation and shows characteristic biologic and clinical features. Blood. 2007; 109:3076-3079. [PubMed: 17138820]

39. Naresh KN. MUM1 expression dichotomises follicular lymphoma into predominantly, MUM1negative low-grade and MUM1-positive high-grade subtypes. Haematologica. 2007; 92:267-268. [PubMed: 17296585]

40. Horsman DE, Connors JM, Pantzar T, Gascoyne RD. Analysis of secondary chromosomal alterations in 165 cases of follicular lymphoma with $\mathrm{t}(14 ; 18)$. Genes Chromosomes Cancer. 2001; 30:375-382. [PubMed: 11241790]

41. Tilly H, Rossi A, Stamatoullas A, et al. Prognostic value of chromosomal abnormalities in follicular lymphoma. Blood. 1994; 84:1043-1049. [PubMed: 8049424]

42. Viardot A, Barth TF, Moller P, et al. Cytogenetic evolution of follicular lymphoma. Semin Cancer Biol. 2003; 13:183-190. [PubMed: 12959349]

43. Viardot A, Moller P, Hogel J, et al. Clinicopathologic correlations of genomic gains and losses in follicular lymphoma. J Clin Oncol. 2002; 20:4523-4530. [PubMed: 12454108]

44. Ross CW, Ouillette PD, Saddler CM, et al. Comprehensive Analysis of Copy Number and Allele Status Identifies Multiple Chromosome Defects Underlying Follicular Lymphoma Pathogenesis. Clin Cancer Res. 2007; 13:4777-4785. [PubMed: 17699855]

45. Hoglund M, Sehn L, Connors JM, et al. Identification of cytogenetic subgroups and karyotypic pathways of clonal evolution in follicular lymphomas. Genes Chromosomes Cancer. 2004; 39:195-204. [PubMed: 14732921]

46. Bastard C, Deweindt C, Kerckaert JP, et al. LAZ3 rearrangements in non-Hodgkin's lymphoma: correlation with histology, immunophenotype, karyotype, and clinical outcome in 217 patients. Blood. 1994; 83:2423-2427. [PubMed: 8167331]

47. Bastard C, Tilly H, Lenormand B, et al. Translocations involving band 3q27 and Ig gene regions in non-Hodgkin's lymphoma. Blood. 1992; 79:2527-2531. [PubMed: 1586704]

48. Horsman DE, Okamoto I, Ludkovski O, et al. Follicular lymphoma lacking the t(14;18)(q32;q21): identification of two disease subtypes. Br J Haematol. 2003; 120:424-433. [PubMed: 12580956] 
49. Katzenberger T, Kalla J, Leich E, et al. A distinctive subtype of t(14;18)-negative nodal follicular non-Hodgkin lymphoma characterized by a predominantly diffuse growth pattern and deletions in the chromosomal region 1p36. Blood. 2009; 113:1053-1061. [PubMed: 18978208]

50. Katzenberger T, Ott G, Klein T, et al. Cytogenetic Alterations Affecting BCL6 Are Predominantly Found in Follicular Lymphomas Grade 3B with a Diffuse Large B-Cell Component. Am J Pathol. 2004; 165:481-490. [PubMed: 15277222]

51. Bosga-Bouwer AG, Haralambieva E, Booman M, et al. BCL6 alternative translocation breakpoint cluster region associated with follicular lymphoma grade 3B. Genes Chromosomes Cancer. 2005; 44:301-304. [PubMed: 16075463]

52. Bosga-Bouwer AG, van den Berg A, Haralambieva E, et al. Molecular, cytogenetic, and immunophenotypic characterization of follicular lymphoma grade $3 \mathrm{~B}$; a separate entity or part of the spectrum of diffuse large B-cell lymphoma or follicular lymphoma? Hum Pathol. 2006; 37:528-533. [PubMed: 16647949]

53. Bosga-Bouwer AG, van Imhoff GW, Boonstra R, et al. Follicular lymphoma grade 3B includes 3 cytogenetically defined subgroups with primary $\mathrm{t}(14 ; 18), 3 \mathrm{q} 27$, or other translocations: $\mathrm{t}(14 ; 18)$ and 3q27 are mutually exclusive. Blood. 2003; 101:1149-1154. [PubMed: 12529293]

54. Diaz-Alderete A, Doval A, Camacho F, et al. Frequency of BCL2 and BCL6 translocations in follicular lymphoma: relation with histological and clinical features. Leuk Lymphoma. 2008; 49:95-101. [PubMed: 18203018]

55. Leich E, Salaverria I, Bea S, et al. Follicular lymphomas with and without translocation $t(14 ; 18)$ differ in gene expression profiles and genetic alterations. Blood. 2009; 114:826-834. [PubMed: 19471018]

56. Braziel RM, Arber DA, Slovak ML, et al. The Burkitt-like lymphomas: a Southwest Oncology Group study delineating phenotypic, genotypic, and clinical features. Blood. 2001; 97:3713-3720. [PubMed: 11389007]

57. McClure RF, Remstein ED, Macon WR, et al. Adult B-cell lymphomas with burkitt-like morphology are phenotypically and genotypically heterogeneous with aggressive clinical behavior. Am J Surg Pathol. 2005; 29:1652-1660. [PubMed: 16327438]

58. Carbone A, Gloghini A, Aiello A, et al. B-cell lymphomas with features intermediate between distinct pathologic entities. From pathogenesis to pathology. Hum Pathol. 2010; 41:621-631. [PubMed: 20398809]

59. de Jong D. Novel lymphoid neoplasms--the borderland between diffuse large B-cell lymphoma and Burkitt's lymphoma. Haematologica. 2009; 94:894-896. [PubMed: 19570750]

60. Wu D, Wood BL, Dorer R, Fromm JR. "Double-Hit" mature B-cell lymphomas show a common immunophenotype by flow cytometry that includes decreased CD20 expression. Am J Clin Pathol. 2010; 134:258-265. [PubMed: 20660329]

61. Christie L, Kernohan N, Levison D, et al. C-MYC translocation in $\mathrm{t}(14 ; 18)$ positive follicular lymphoma at presentation: An adverse prognostic indicator? Leuk Lymphoma. 2008; 49:470-476. [PubMed: 18297523]

62. Le Gouill S, Talmant $\mathrm{P}$, Touzeau $\mathrm{C}$, et al. The clinical presentation and prognosis of diffuse large B-cell lymphoma with $\mathrm{t}(14 ; 18)$ and 8q24/c-MYC rearrangement. Haematologica. 2007; 92:13351342. [PubMed: 18024371]

63. Lin P, Medeiros LJ. High-grade B-cell lymphoma/leukemia associated with t(14;18) and 8q24/ MYC rearrangement: a neoplasm of germinal center immunophenotype with poor prognosis. Haematologica. 2007; 92:1297-1301. [PubMed: 18024366]

64. Macpherson N, Lesack D, Klasa R, et al. Small noncleaved, non-Burkitt's (Burkitt-Like) lymphoma: cytogenetics predict outcome and reflect clinical presentation. J Clin Oncol. 1999; 17:1558-1567. [PubMed: 10334544]

65. Niitsu N, Okamoto M, Miura I, Hirano M. Clinical features and prognosis of de novo diffuse large B-cell lymphoma with t(14;18) and 8q24/c-MYC translocations. Leukemia. 2009

66. Boerma EG, Siebert R, Kluin PM, Baudis M. Translocations involving 8q24 in Burkitt lymphoma and other malignant lymphomas: a historical review of cytogenetics in the light of todays knowledge. Leukemia. 2009:225-234. [PubMed: 18923440] 
67. Hummel M, Bentink S, Berger H, et al. A biologic definition of Burkitt's lymphoma from transcriptional and genomic profiling. The New England journal of medicine. 2006; 354:24192430. [PubMed: 16760442]

68. Kramer MH, Raghoebier S, Beverstock GC, et al. De novo acute B-cell leukemia with translocation $t(14 ; 18)$ : an entity with a poor prognosis. Leukemia. 1991; 5:473-478. [PubMed: 1711639]

69. Natkunam Y, Warnke RA, Zehnder JL, et al. Blastic/blastoid transformation of follicular lymphoma: immunohistologic and molecular analyses of five cases. Am J Surg Pathol. 2000; 24:525-534. [PubMed: 10757399]

70. Glas AM, Knoops L, Delahaye L, et al. Gene-expression and immunohistochemical study of specific T-cell subsets and accessory cell types in the transformation and prognosis of follicular lymphoma. Journal of clinical oncology. 2007; 25:390-398. [PubMed: 17200149]

71. Davies AJ, Rosenwald A, Wright G, et al. Transformation of follicular lymphoma to diffuse large B-cell lymphoma proceeds by distinct oncogenic mechanisms. British journal of haematology. 2007; 136:286-293. [PubMed: 17278262]

72. Johnson NA, Savage KJ, Ludkovski O, et al. Lymphomas with concurrent BCL2 and MYC translocations: the critical factors associated with survival. Blood. 2009; 114:2273-2279. [PubMed: 19597184]

73. Relander T, Johnson NA, Farinha P, et al. Prognostic factors in follicular lymphoma. J Clin Oncol. 2010; 28:2902-2913. [PubMed: 20385990]

74. de Jong D. Molecular pathogenesis of follicular lymphoma: a cross talk of genetic and immunologic factors. J Clin Oncol. 2005; 23:6358-6363. [PubMed: 16155020]

75. De Jong D, de Boer JP. Predicting transformation in follicular lymphoma. Leuk Lymphoma. 2009:1-6.

76. Farinha P, Masoudi H, Skinnider BF, et al. Analysis of multiple biomarkers shows that lymphomaassociated macrophage (LAM) content is an independent predictor of survival in follicular lymphoma (FL). Blood. 2005; 106:2169-2174. [PubMed: 15933054]

77. Kuppers R. Mechanisms of B-cell lymphoma pathogenesis. Nat Rev Cancer. 2005; 5:251-262. [PubMed: 15803153]

78. Carlotti E, Wrench D, Matthews J, et al. Transformation of follicular lymphoma to diffuse large Bcell lymphoma may occur by divergent evolution from a common progenitor cell or by direct evolution from the follicular lymphoma clone. Blood. 2009; 113:3553-3557. [PubMed: 19202129]

79. Ruminy P, Jardin F, Picquenot JM, et al. S(mu) mutation patterns suggest different progression pathways in follicular lymphoma: early direct or late from FL progenitor cells. Blood. 2008; 112:1951-1959. [PubMed: 18515657]

80. Wrench D, Montoto S, Fitzgibbon J. Molecular signatures in the diagnosis and management of follicular lymphoma. Curr Opin Hematol. 2010; 17:333-340. [PubMed: 20571396]

81. d'Amore F, Chan E, Iqbal J, et al. Clonal Evolution in t(14;18)-Positive Follicular Lymphoma, Evidence for Multiple Common Pathways, and Frequent Parallel Clonal Evolution. Clin Cancer Res. 2008; 14:7180-7187. [PubMed: 19010834]

82. Carlotti E, Gribben JG. Stem cell mimicry: key to transformation? Blood. 2009; 114:3133-3134. [PubMed: 19815676]

83. Gentles AJ, Alizadeh AA, Lee S-I, et al. A pluripotency signature predicts histologic transformation and influences survival in follicular lymphoma patients. Blood. 2009; 114:31583166. [PubMed: 19636063]

84. Shiozawa E, Yamochi-Onizuka T, Yamochi T, et al. Disappearance of CD21-positive follicular dendritic cells preceding the transformation of follicular lymphoma: immunohistological study of the transformation using CD21, p53, Ki-67, and P-glycoprotein. Pathol Res Pract. 2003; 199:293302. [PubMed: 12908519]

85. Yoon SO, Zhang X, Freedman AS, et al. Down-regulation of CD9 expression and its correlation to tumor progression in B lymphomas. Am J Pathol. 2010; 177:377-386. [PubMed: 20566742]

86. Lo Coco F, Gaidano G, Louie DC, et al. p53 mutations are associated with histologic transformation of follicular lymphoma. Blood. 1993; 82:2289-2295. [PubMed: 8400281] 
87. Sander CA, Yano T, Clark HM, et al. p53 mutation is associated with progression in follicular lymphomas. Blood. 1993; 82:1994-2004. [PubMed: 8400252]

88. Elenitoba-Johnson KS, Gascoyne RD, Lim MS, et al. Homozygous deletions at chromosome 9p21 involving p16 and p15 are associated with histologic progression in follicle center lymphoma. Blood. 1998; 91:4677-4685. [PubMed: 9616165]

89. Elenitoba-Johnson KS, Jenson SD, Abbott RT, et al. Involvement of multiple signaling pathways in follicular lymphoma transformation: p38-mitogen-activated protein kinase as a target for therapy. Proc Natl Acad Sci U S A. 2003; 100:7259-7264. [PubMed: 12756297]

90. Moller MB, Nielsen O, Pedersen NT. Frequent alteration of MDM2 and p53 in the molecular progression of recurring non-Hodgkin's lymphoma. Histopathology. 2002; 41:322-330. [PubMed: 12383214]

91. Bernell P, Jacobsson B, Liliemark J, et al. Gain of chromosome 7 marks the progression from indolent to aggressive follicle centre lymphoma and is a common finding in patients with diffuse large B-cell lymphoma: a study by FISH. Br J Haematol. 1998; 101:487-491. [PubMed: 9633892]

92. Hough RE, Goepel JR, Alcock HE, et al. Copy number gain at 12q12-14 may be important in the transformation from follicular lymphoma to diffuse large B cell lymphoma. Br J Cancer. 2001; 84:499-503. [PubMed: 11207045]

93. Boonstra R, Bosga-Bouwer A, Mastik M, et al. Identification of chromosomal copy number changes associated with transformation of follicular lymphoma to diffuse large B-cell lymphoma. Hum Pathol. 2003; 34:915-923. [PubMed: 14562288]

94. Akasaka T, Lossos IS, Levy R. BCL6 gene translocation in follicular lymphoma: a harbinger of eventual transformation to diffuse aggressive lymphoma. Blood. 2003; 102:1443-1448. [PubMed: 12738680]

95. Matolcsy A, Warnke RA, Knowles DM. Somatic mutations of the translocated bcl-2 gene are associated with morphologic transformation of follicular lymphoma to diffuse large-cell lymphoma. Annals of Oncology. 1997; 8:119-122. [PubMed: 9209654]

96. Cheung KJ, Shah SP, Steidl C, et al. Genome-wide profiling of follicular lymphoma by array comparative genomic hybridization reveals prognostically significant DNA copy number imbalances. Blood. 2009; 113:137-148. [PubMed: 18703704]

97. Cheung K-J, Johnson N, Affleck J, et al. TNFRSF14 Is Mutated in a Subset of Follicular Lymphoma and Correlated with Inferior Prognosis. ASH Annual Meeting Abstracts. 2009; 114:1919.

98. Johnson NA, Morin R, Severson T, et al. FAS Mutations in Follicular Lymphoma Are Rare but Associated with Aggressive Clinical Behavior. ASH Annual Meeting Abstracts. 2009; 114:3967.

99. O'Shea D, O'Riain C, Gupta M, et al. Regions of acquired uniparental disomy at diagnosis of follicular lymphoma are associated with both overall survival and risk of transformation. Blood. 2009; 113:2298-2301. [PubMed: 19141865]

100. Dave SS, Wright G, Tan B, et al. Prediction of survival in follicular lymphoma based on molecular features of tumor-infiltrating immune cells. N Engl J Med. 2004; 351:2159-2169. [PubMed: 15548776]

101. de Jong D, Koster A, Hagenbeek A, et al. Impact of the tumor microenvironment on prognosis in follicular lymphoma is dependent on specific treatment protocols. Haematologica. 2009; 94:7077. [PubMed: 19059937]

102. Carreras J, Lopez-Guillermo A, Fox BC, et al. High numbers of tumor-infiltrating FOXP3positive regulatory $\mathrm{T}$ cells are associated with improved overall survival in follicular lymphoma. Blood. 2006; 108:2957-2964. [PubMed: 16825494]

103. Farinha P, Al-Tourah A, Gill K, et al. The architectural pattern of FOXP3-positive T cells in follicular lymphoma is an independent predictor of survival and histologic transformation. Blood. 2010; 115:289-295. [PubMed: 19901260]

104. Carreras J, Lopez-Guillermo A, Roncador G, et al. High Numbers of Tumor-Infiltrating Programmed Cell Death 1-Positive Regulatory Lymphocytes Are Associated With Improved Overall Survival in Follicular Lymphoma. J Clin Oncol. 2009; 27:1470-1476. [PubMed: 19224853] 
105. Taskinen M, Karjalainen-Lindsberg ML, Nyman H, et al. A high tumor-associated macrophage content predicts favorable outcome in follicular lymphoma patients treated with rituximab and cyclophosphamide-doxorubicin-vincristine-prednisone. Clinical cancer research. 2007; 13:57845789. [PubMed: 17908969]

106. Taskinen M, Karjalainen-Lindsberg M-L, Leppa S. Prognostic influence of tumor-infiltrating mast cells in patients with follicular lymphoma treated with rituximab and CHOP. Blood. 2008; 111:4664-4667. [PubMed: 18309035]

107. Farinha P, Kyle A, Minchinton A, et al. Vascularization predicts overall survival and risk of transformation in follicular lymphoma. Haematologica. (epub August 16, 2010).

108. Gine E, Montoto S, Bosch F, et al. The Follicular Lymphoma International Prognostic Index (FLIPI) and the histological subtype are the most important factors to predict histological transformation in follicular lymphoma. Ann Oncol. 2006; 17:1539-1545. [PubMed: 16940035]

109. Yuen AR, Kamel OW, Halpern J, Horning SJ. Long-term survival after histologic transformation of low-grade follicular lymphoma. J Clin Oncol. 1995; 13:1726-1733. [PubMed: 7602362]

110. Noy A, Schoder H, Gonen M, et al. The majority of transformed lymphomas have high standardized uptake values (SUVs) on positron emission tomography (PET) scanning similar to diffuse large B-cell lymphoma (DLBCL). Ann Oncol. 2009; 20:508-512. [PubMed: 19139176]

111. Kaminski MS, Zelenetz AD, Press OW, et al. Pivotal study of iodine I 131 tositumomab for chemotherapy-refractory low-grade or transformed low-grade B-cell non-Hodgkin's lymphomas. J Clin Oncol. 2001; 19:3918-3928. [PubMed: 11579112]

112. Vose JM, Wahl RL, Saleh M, et al. Multicenter phase II study of iodine-131 tositumomab for chemotherapy-relapsed/refractory low-grade and transformed low-grade B-cell non-Hodgkin's lymphomas. J Clin Oncol. 2000; 18:1316-1323. [PubMed: 10715303]

113. Davies AJ, Rohatiner AZ, Howell S, et al. Tositumomab and iodine I 131 tositumomab for recurrent indolent and transformed B-cell non-Hodgkin's lymphoma. J Clin Oncol. 2004; 22:1469-1479. [PubMed: 15084620]

114. Witzig TE, Gordon LI, Cabanillas F, et al. Randomized controlled trial of yttrium-90-labeled ibritumomab tiuxetan radioimmunotherapy versus rituximab immunotherapy for patients with relapsed or refractory low-grade, follicular, or transformed B-cell non-Hodgkin's lymphoma. J Clin Oncol. 2002; 20:2453-2463. [PubMed: 12011122]

115. Schouten HC, Bierman PJ, Vaughan WP, et al. Autologous bone marrow transplantation in follicular non-Hodgkin's lymphoma before and after histologic transformation. Blood. 1989; 74:2579-2584. [PubMed: 2804380]

116. Freedman AS, Ritz J, Neuberg D, et al. Autologous bone marrow transplantation in 69 patients with a history of low-grade B-cell non-Hodgkin's lymphoma. Blood. 1991; 77:2524-2529. [PubMed: 2039834]

117. Foran JM, Apostolidis J, Papamichael D, et al. High-dose therapy with autologous haematopoietic support in patients with transformed follicular lymphoma: a study of 27 patients from a single centre. Ann Oncol. 1998; 9:865-869. [PubMed: 9789609]

118. Berglund A, Enblad G, Carlson K, et al. Long-term follow-up of autologous stem-cell transplantation for follicular and transformed follicular lymphoma. Eur J Haematol. 2000; 65:1722. [PubMed: 10914935]

119. Chen CI, Crump M, Tsang R, et al. Autotransplants for histologically transformed follicular nonHodgkin's lymphoma. Br J Haematol. 2001; 113:202-208. [PubMed: 11328303]

120. Williams CD, Harrison CN, Lister TA, et al. High-dose therapy and autologous stem-cell support for chemosensitive transformed low-grade follicular non-Hodgkin's lymphoma: a case-matched study from the European Bone Marrow Transplant Registry. J Clin Oncol. 2001; 19:727-735. [PubMed: 11157024]

121. Friedberg JW, Neuberg D, Gribben JG, et al. Autologous bone marrow transplantation after histologic transformation of indolent B cell malignancies. Biol Blood Marrow Transplant. 1999; 5:262-268. [PubMed: 10465106]

122. Andreadis C, Schuster SJ, Chong EA, et al. Long-term event-free survivors after high-dose therapy and autologous stem-cell transplantation for low-grade follicular lymphoma. Bone Marrow Transplant. 2005; 36:955-961. [PubMed: 16205727] 
123. Sabloff M, Atkins HL, Bence-Bruckler I, et al. A 15-year analysis of early and late autologous hematopoietic stem cell transplant in relapsed, aggressive, transformed, and nontransformed follicular lymphoma. Biol Blood Marrow Transplant. 2007; 13:956-964. [PubMed: 17640600]

124. Ramadan KM, Connors JM, Al-Tourah AJ, et al. Autologous stem cell transplantation is superior to myeloablative allogeneic SCT as a salvage therapy for patients with refractory/relapsed transformed lymphoma. Blood. 2008; 112:4459.

125. Rezvani AR, Storer B, Maris M, et al. Nonmyeloablative allogeneic hematopoietic cell transplantation in relapsed, refractory, and transformed indolent non-Hodgkin's lymphoma. J Clin Oncol. 2008; 26:211-217. [PubMed: 18056679] 

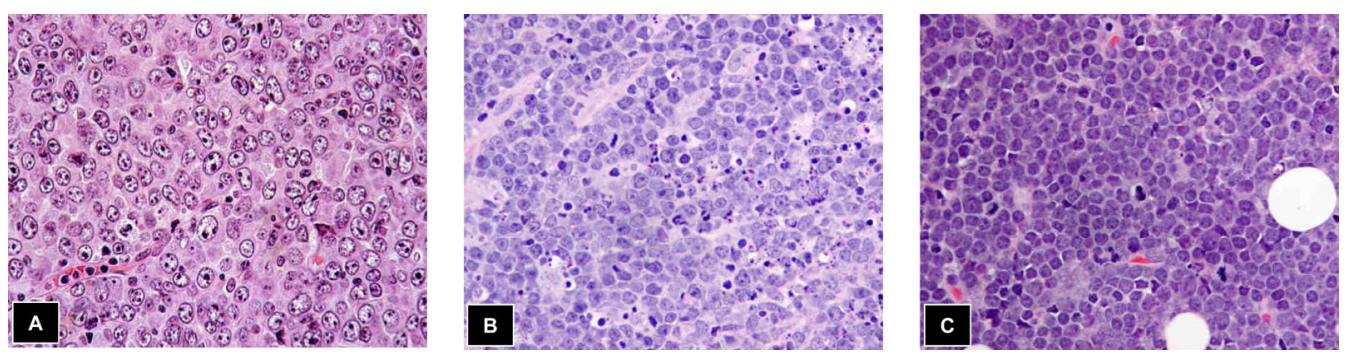

Figure 1.

Transformation of FL to aggressive lymphoma most commonly takes one of three forms, A) diffuse large B cell lymphoma, B) unclassifiable B cell lymphoma with features intermediate between DLBCL and Burkitt lymphoma and finally, C) a blastoid lymphoma with fine chromatin (rare $\mathrm{Tdt}^{+}$blastoid lymphomas may be seen as a transformation event following FL that show double-hit cytogenetics with translocations of BCL2 and MYC) 


\section{Genetic lesions in the tumor cells \\ .p53 loss \\ - $p 16 / C D K N 2 A$ loss \\ - $M Y C$ deregulation \\ -+12/12q13-14 gain \\ -BCL6 translocations \\ -Mutations in BCL2/BCL6 \\ -Deletion/UPD $1 \mathrm{p} 36$ \\ (TNFRSF14) \\ -Deletion 6q \\ -Trisomy 7 \\ - FAS mutations \\ -UPD 16p \\ -CD9 loss \\ Changes in the micro environment \\ (non-neoplastic cells)}

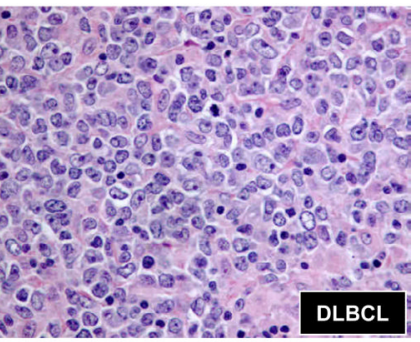

DLBCL

$$
\begin{gathered}
\text {-FDC loss or immaturity } \\
\text {-Increased intrafollicular } \\
\text { CD4 } 4^{+} \mathrm{T} \text { cells } \\
\text {-Pattern and number of } \\
\text { regulatory T cells } \\
\text {-Decreased PD-1+T cells } \\
\text {-Increased MVD }
\end{gathered}
$$

Figure 2.

Biological factors associated with histologic transformation of FL to DLBCL. These include both genetic alterations harbored by the malignant B cells and factors that influence the tumoral microenvironment. UPD = uniparental dizomy, FDC = follicular dendritic cells, PD $=$ programmed death and MVD = microvessel density. 
Anthracycline-Naïve t-FL
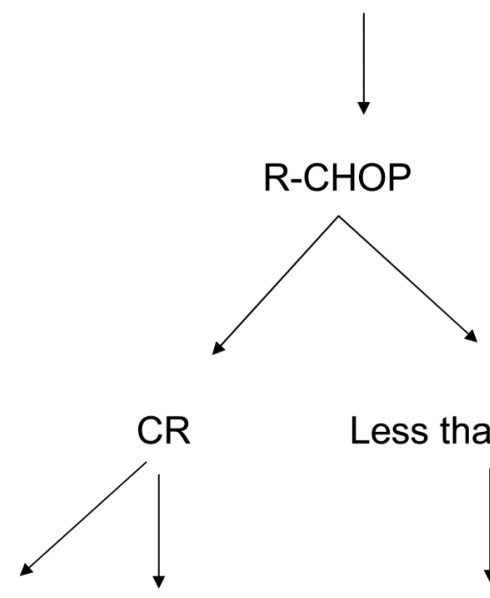

Not Limited

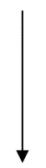

Radiation

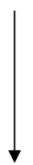

Limited extent

Figure 3.

Suggested therapeutic approach to patients with transformed FL.
Anthracycline-Experienced $\mathrm{t}-\mathrm{FL}$

Limited extent Not Limited

RIT may be considered

in selected cases

Observation 


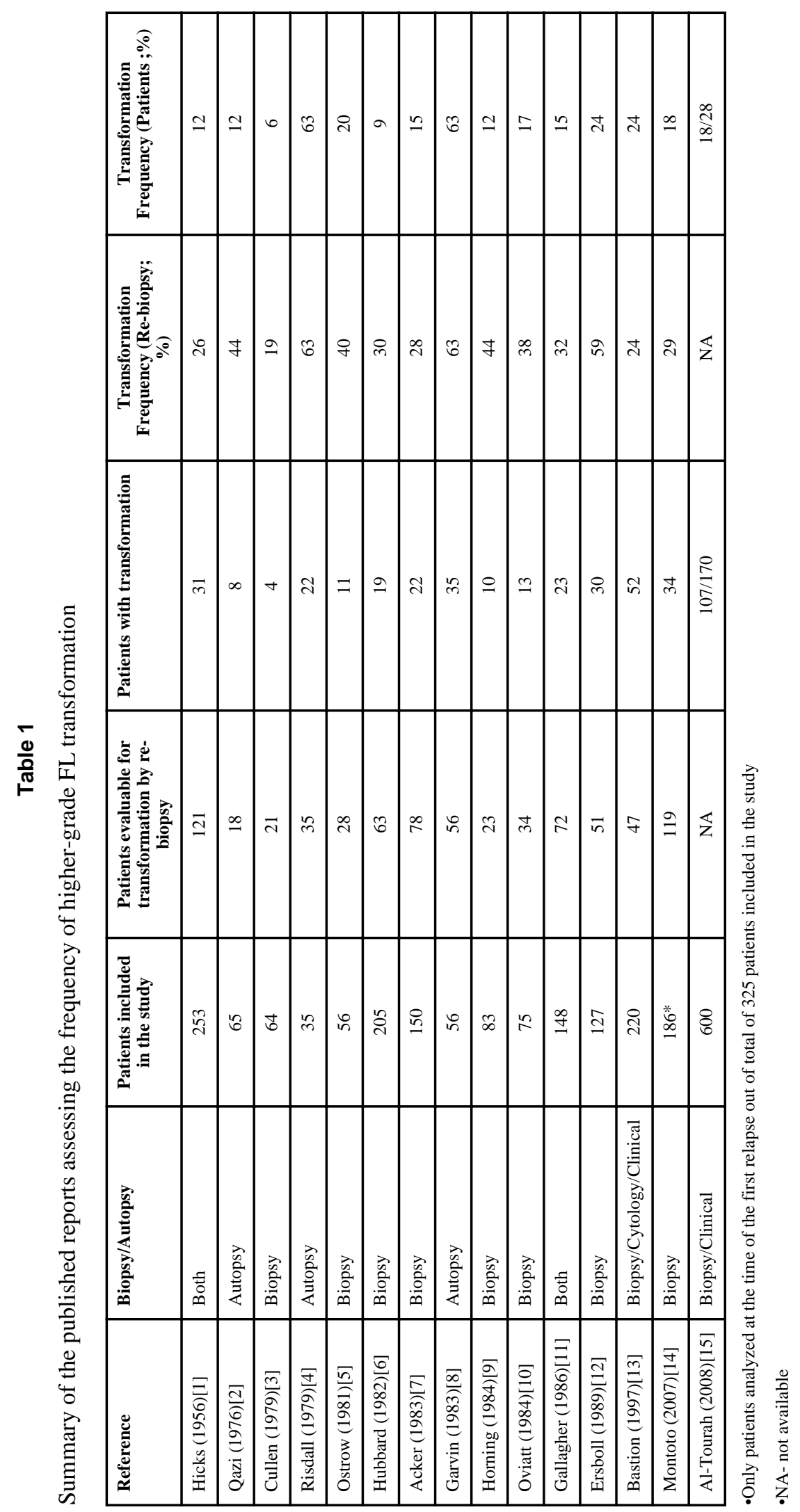


Table 2

Classification of transformed biopsies in follicular lymphoma patients

\begin{tabular}{|c|c|c|}
\hline Histologic Subtype & Morphologic Features & Comments \\
\hline $\begin{array}{l}\text { Diffuse large B cell } \\
\text { lymphoma }\end{array}$ & $\begin{array}{l}\text {-Typically sheets of centroblasts and/or } \\
\text { immunoblasts } \\
\text {-Follicular architecture is lost, although some } \\
\text { residual follicular structures may be evident }\end{array}$ & $\begin{array}{c}\text {-The immunophenotype is characteristically similar to } \\
\text { FL }\left(\mathrm{CD} 10^{+}, \mathrm{BCL}^{+}, \mathrm{BCL} 2^{+}\right) \text {i.e. GCB profile } \\
\text {-Cytogenetics usually complex, but } \mathrm{t}(14 ; 18) \text { is a stable } \\
\text { marker and so typically present } \\
-M Y C \text { translocations maybe present }\end{array}$ \\
\hline $\begin{array}{l}\text { Unclassifiable B cell } \\
\text { lymphomas with features } \\
\text { intermediate between } \\
\text { DLBCL and Burkitt } \\
\text { lymphoma (BCLU) }\end{array}$ & $\begin{array}{c}\text {-Diffuse infiltrate of medium sized cells, often with } \\
\text { admixed larger centroblasts } \\
\text {-May show starry-sky pattern } \\
\text {-Variable mitotic activity }\end{array}$ & $\begin{array}{c}\text {-Most cases are BCL2 protein positive and show a GCB } \\
\text { immunophenotype } \\
\text {-Proliferative rate with Ki67 is often < } 95 \% \\
\text {-Dual translocation cases are common (both BCL2 and/ } \\
\text { or BCL6 and MYC translocations) }\end{array}$ \\
\hline Blastoid & $\begin{array}{c}\text {-Sheets of immature B cells with fine chromatin and } \\
\text { absent nucleoli } \\
\text {-Mitoses frequent } \\
\text {-Some residual follicles maybe seen }\end{array}$ & $\begin{array}{l}\text {-Characteristic FL phenotype } \\
\text {-Despite blastoid morphology, nuclear Tdt is negative }\end{array}$ \\
\hline Lymphoblastic & $\begin{array}{l}\text {-Sheets of immature B cells with fine chromatin and } \\
\text { absent nucleoli } \\
\text {-Mitoses frequent }\end{array}$ & $\begin{array}{l}\text {-The immunophenotype maybe mixed, but typically } \\
\text { CD } 10^{+}, \text {BCL6 }{ }^{+} \\
\text {-Tdt is positive, but maybe variable } \\
\text {-Cytogenetics reveals dual translocations involving } \\
\text { BCL2 and } M Y C \text { oncogenes }\end{array}$ \\
\hline
\end{tabular}


Table 3

Biological factors associated with FL transformation

\begin{tabular}{|c|c|c|c|}
\hline Cell Type & Biological Factor & Mechanism & References \\
\hline \multicolumn{4}{|c|}{ Neoplastic B cells } \\
\hline & Diffuse architecture & Lose dependence on stroma & 33,70 \\
\hline & P53 loss and/or mutation & Loss of tumor suppressor & $44,86,87$ \\
\hline & $P 16 / C D K N 2 A / B$ loss or hypermethylation & Loss of tumor suppressor & 88 \\
\hline & $\begin{array}{c}\text { MYC translocation, mutations and } \\
\text { deregulation }\end{array}$ & $\begin{array}{l}\text { Dominant oncogene driving widespread gene } \\
\text { expression changes }\end{array}$ & $24,71,72$ \\
\hline & Deletion $1 \mathrm{p} 36.3$ & $\begin{array}{c}\text { Loss of TNFRSF14 gene, a candidate tumor } \\
\text { suppressor }\end{array}$ & $44,96,97$ \\
\hline & Deletion 6q & Gene(s) unidentified & 44,96 \\
\hline & +12 or gain $12 q 13-14$ & Gene(s) unidentified & 92 \\
\hline & +7 & Gene(s) unidentified & 91 \\
\hline & UPD chromosome 16p & Gene(s) unidentified & 99 \\
\hline & $B C L 6$ translocations & Unknown & 27,90 \\
\hline & Mutations in $B C L 2$ or $B C L 6$ & Unknown & 27,94 \\
\hline & Mutations in FAS on chromosome 10q & Anti-apoptotic due to loss of the death domain & 29,98 \\
\hline & Loss of CD9 expression & Epigenetically controlled loss of FDC dependence & 85 \\
\hline & Pluripotency gene expression signature & $\begin{array}{l}\text { Expression of an embryonic stem cell-like } \\
\text { signature }\end{array}$ & 83 \\
\hline \multicolumn{4}{|c|}{$\begin{array}{l}\text { Non-neoplastic cells } \\
\text { in the tumor } \\
\text { microenvironment }\end{array}$} \\
\hline & FDC loss or immaturity & FL B cells lose dependency on stromal support & $33,70,84,85$ \\
\hline & Increased intrafollicular $\mathrm{CD}^{+} \mathrm{T}$ cells & Unknown & 70 \\
\hline & Regulatory T cells $\left(\mathrm{FOXP} 3^{+}\right)$ & $\begin{array}{l}\text { Numbers and pattern may influence risk of } \\
\text { transformation by an unknown mechanism }\end{array}$ & 102,103 \\
\hline & $\mathrm{PD}-1^{+} \mathrm{T}$ cells & Unknown & 104 \\
\hline & Increased MVD & Unknown & 107 \\
\hline
\end{tabular}

Abbreviations: UPD $=$ uniparental dizomy, $\mathrm{FDC}=$ follicular dendritic cells, $\mathrm{MVD}=$ microvessel density 
Table 4

Outcome of FL post transformation

\begin{tabular}{|l|c|c|c|c|}
\hline Reference & $\begin{array}{c}\text { Number of } \\
\text { Transformation patients }\end{array}$ & $\begin{array}{c}\text { Median Survival After } \\
\text { Transformation (months) }\end{array}$ & $\begin{array}{c}\text { Median Survival of } \\
\text { Patients Achieving CR } \\
\text { (months) }\end{array}$ & $\begin{array}{c}\text { Median Survival of } \\
\text { Patients Not Achieving } \\
\text { CR (months) }\end{array}$ \\
\hline Armitage (1981)[19] & 14 & 12 & 2.5 & NA \\
\hline Hubbard (1982)[6] & 19 & 11 & 40.5 & 4 \\
\hline Acker (1983)[7] & 22 & 8.5 & Not reached & NA \\
\hline Oviatt (1984)[10] & 13 & 2.5 & NA & NA \\
\hline Yuen (1995)[109] & 74 & 22 & 81 & NA \\
\hline Bastion (1997)[13] & 52 & 7 & NA & $5^{*}$ and $12^{* *}$ \\
\hline Montoto(2007)[14] & 88 & 14 & 67 & NA \\
\hline Al-Tourah (2008)[15] & 170 & 20 & NA & \\
\hline
\end{tabular}

* Patients with no response to salvage therapy

Patients with partial response to salvage therapy 


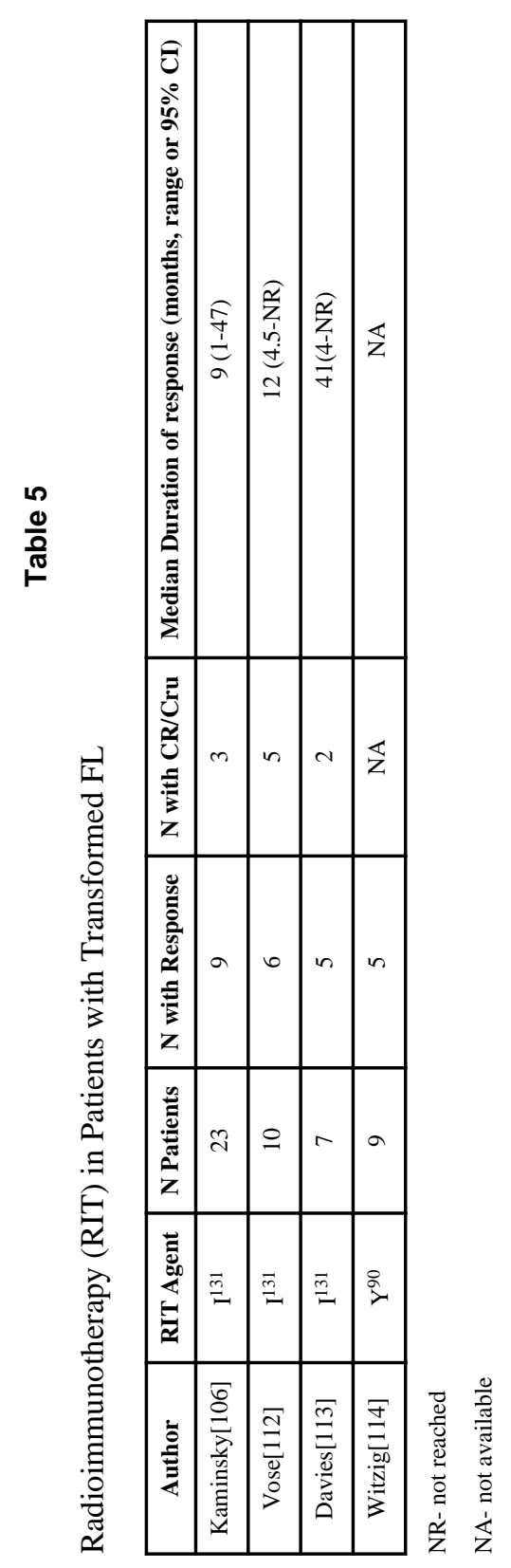

Best Pract Res Clin Haematol. Author manuscript; available in PMC 2012 June 1. 


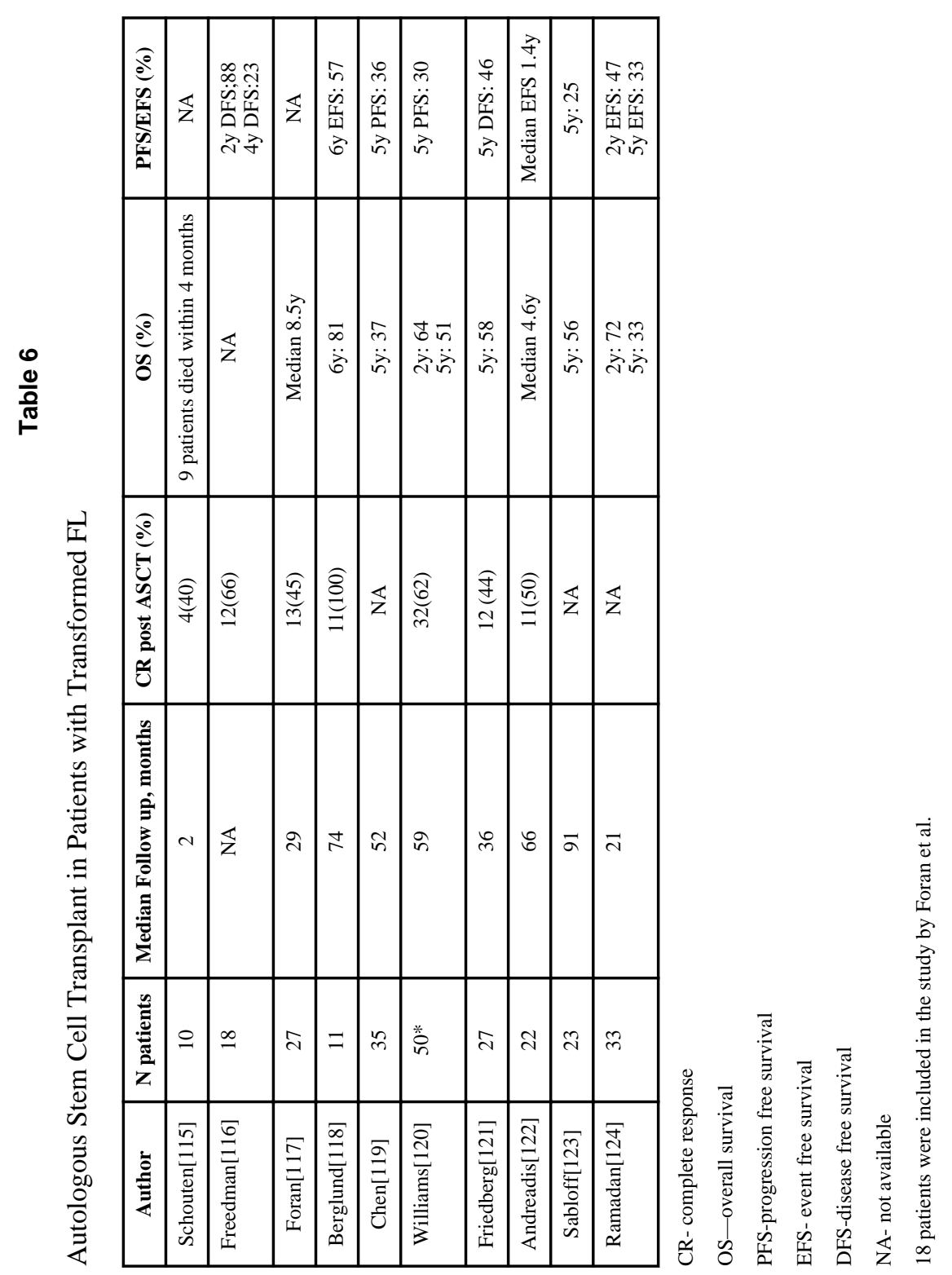

Best Pract Res Clin Haematol. Author manuscript; available in PMC 2012 June 1. 